\title{
The Sustainable Management of Cultural Heritage Sites: Tourism and the Politics of Archaeology at Petra
}

\author{
Maxwell Saltman \\ History and Archaeology, \\ Sewanee: The University of the South, \\ Sewanee, Tennessee, USA

\section{Dr. Ismaiel Abuamoud} \\ Associate Professor, \\ School of Archaeology and Tourism, \\ Department of Tourism Management, \\ University of Jordan, Amman, Jordan
}

DOI: https://doi.org/10.36941/ajis-2020-0o6o

\begin{abstract}
Jordan is a country rich with history, both modern and ancient, and its ancient past is best reflected by the thousands of archaeological sites peppered within its borders. Tourists travel from all over the world to visit Jordan and see its antiquities first-hand, contributing significantly to the ever-important Jordanian tourism industry. The interaction between tourism and archaeology is such that the two subjects share a department at the University of Jordan and a ministry in the Jordanian government. This study explores the political relationship between tourism and archaeology through the lens of Jordan's largest tourist attraction, the ancient city of Petra. In particular, the study asks how archaeologists and tourism experts evaluate the management plans of Petra, whether these two groups find themselves in conflict or not, and whether the relationship between tourism and archaeology has squandered the many attempts at implementing a management plan at the Petra site. This study used both qualitative data in the form of interviews with academics, businesspeople, and government officials, and quantitative data in the form of a survey of faculty at the University of Jordan. The result revealed that respondents are split between those who think tourism and archaeology are destined to clash, and those who think that archaeology should adapt to the needs of tourism.
\end{abstract}

Keywords: Sustainable Management, Cultural Heritage, Tourism, Archaeology, Petra

\section{Introduction}

Jordan cultural heritage sites are considered one of the most powerful draws for international visitors to the country, (Abuamoud, et al., 2014). Tourism is widely seen as an engine for economic growth in many countries, especially developing ones (Pratt, 2015; Hrubcova, Loster, \& Obergruber, 2016; ErkuşÖztürk \& Terhorst, 2018). Tourism and archaeology are central to both Jordanian national identity and Jordanian economy. Nearly anywhere one goes in Jordan, the familiar image of Al-Khazneh, the most famous of Petra's many rock-cut Hellenistic façades, can be found printed on t-shirts, book bags, mugs, ashtrays, and posters. 
In a country with little water and no oil, Jordan's cultural heritage remains one of its most potent resources (Abuamoud, et al., 2014). And yet, archaeological heritage is distinct from resources like oil or water in its incredibly strict limitations. It cannot be exploited in the way that oil or water can. Money is made from monetizing access to heritage sites, or from vendors operating around the site. In many ways, archaeological heritage is the most non-renewable of non-renewable resources (Krautkraemer, 1998). Minute changes in the environment of an archaeological site can mean the irrevocable loss of crucial data about the past (Sevara, et al., 2017). And yet, as this paper will discuss, tourism at archaeological sites by its very nature will change the environment around the site, both physically and politically.

The tourism industry grows daily in Jordan, and in Petra especially. In October 2019 alone, the revenues from tourism grew 9.4 percent. According to the Central Bank of Jordan, tourism in October brought in $\$ 458.4$ million (approximately JD325 million) (CBJ, 2019). Visitation to Petra specifically increased some 43 percent, according to figures released by the Ministry of Tourism and Antiquities. (Jordan Times, 2019) This is in line with predictions made in early November. (Jordan New Agency, 2019) On November 21, 2019, visitation to Petra reached one million visitors per year, the highest in recent history. (Arshani, 2019) Additionally, visitation in 2019 increased significantly among both foreigners and Jordanians. In October 2018, 96,414 people visited, among them 1,128 Jordanians and Arabs, and 85, 149 foreign visitors. In 2019, however, 11,438 out of the 137,789 tourists to Petra were Arab or Jordanian, an increase of over 10,00o. (Roya News, 2019 )

The seed of interest for this paper emerged from the question of "who owns the past?" and the importance of tourism in Jordan and its relationship with archaeology. Tourism and its close relationship with antiquities in Jordan is a fascinating lens with which to observe the politics of Jordanian archaeology.

This paper uses Petra, the most famous of Jordan's many archaeological sites, as a circuit for researching tourism, archaeology, and politics. It will delve, briefly, into the history of the site, but the primary focus will be on modern efforts towards preparing the site for tourism, archaeological concerns surrounding Petra, and the politics of tourism at this archaeological site. The paper will also discuss what Petra and its position might say about the story of tourism and archaeology in Jordan as a whole, including in government and academia.

To that end, the study tries to answer the questions: what do archaeologists and tourism experts think about the structure of how tourism and archaeology are managed?

- Are archaeologists and tourism advocates in conflict? Are these groups mutually exclusive?

- Is it possible to implement a comprehensive management plan at Petra?

Throughout the paper, terms like cultural heritage, archaeology, and tourism are used frequently. For the sake of clarity, the terms are defined here. Cultural heritage is understood using the definition provided by the World Heritage Convention Operational Guidelines:

"Monuments: architectural works, works of monumental sculpture and painting, elements or structures of an archaeological nature, inscriptions, cave dwellings and combinations of features, which are of outstanding universal value from the point of view of history, art or science.

Groups of buildings: groups of separate or connected buildings which, because of their architecture, their homogeneity or their place in the landscape are of outstanding universal value from the point of view of history, art, or science.

Sites: works of man or the combined works of nature and of man, and areas including archaeological sites which are of outstanding universal value from the historical, aesthetic, ethnological, or anthropological points of view." (Dizdaroglu, 2004)

Archaeology is defined in this paper as the study of the human past, both historic and prehistoric, through the excavation of sites and the analysis of artifacts and remains (Lightfoot, 1995).

Tourism is understood to be the business operations related to vacations and visits to places of interest, both international and local (UNWTO, 2017). 


\section{Literature Review}

Who owns the past? Under whose authority is the past remembered? In his review of the political uses of archaeology in 1987, anthropologist Donald D. Fowler wrote that "since its inception as a field of study and later as a discipline, archaeology has been immersed in, and conditioned by, the economic, political, and governmental institutions of nation states." It remains a self-evident truth that much of the politics in archaeology comes down to authority. As Fowler pointed out, these questions of authority can have answers grounded in nationalism, where archaeology has been used as a means of raising the past of a nation, and of validating a civilizations right to exist. (Fowler, 1987) Yet these questions can also be answered in practical means, focusing more on the power of institutions rather than that of ideology or identity.

Institutional authority over heritage was a mainstay of colonial-era incursions into the Levant. In the $19^{\text {th }}$ century, Orientalists, missionaries, and archaeologists from Britain began sifting through the Levantine soil, looking for evidence of Biblical-era heroes and cities. Between 1871 and 1877, British surveyors crafted surveys of Western Palestine and Eastern Palestine. This was a project intended to give "scientific articulation to the Holy Land by mapping it, using the River Jordan as the border between west and east." (Corbett, 2014)

\subsection{Tourism and Archaeology in Jordan}

According to their website, the Jordanian Department of Antiquities was established under the British-ruled Emirate of Transjordan in 1923. Under its charter, the department was also responsible for tourism in Jordan until 1967 , it was upgraded to ministry status. (Anon., n.d.)

Today, like in pre-1953 Jordan, archaeology and tourism in Jordan are governed under the auspices of the same ministry, the Ministry of Tourism and Antiquities. This relationship is unusual, but its existence makes a modicum of sense when one considers the economic importance of tourism, and the importance of archaeology within the Jordanian tourism industry. According to the United Nations, tourism makes up some $10 \%$ of Jordan's economy (CBJ, 2019). Much of the tourism within Jordan is archaeological, with special emphasis on Petra, Jordan's most visited site. (Anon., n.d.)

A key difference between the present status of the relationship between tourism and antiquities in Jordan and the past relationship is that whereas in 1923, tourism was governed under the Department of Antiquities, today, the Department of Antiquities is under the Ministry of Tourism.

\subsection{Petra}

The modern name "Petra" derives from the Greek word for "rock" (similar to the male name "Peter" or "Petros"), and refers to the city's famous sandstone tombs, carved in a mishmash of Hellenistic, Roman, and native Nabatean styles. The most famous of these tombs, the iconic Al-Khazneh, stands carved directly into the sandstone, and is immediately and dramatically visible when visitors exit the gorge known as the Siq.

The Aramaic-speaking Nabateans for whom Petra served as a capital were ancient capitalists of the highest order. Petra was a thriving metropolis at the center of a region-wide spice and incense trade. "When Petra was the capital of their kingdom," writes Christopher A. Tuttle, "The Nabateans controlled most, if not all, of the overland trade routes bringing luxury goods across the sands of Arabia to Mediterranean ports and commercial centers in the areas of modern Syria and Iraq." (Tuttle, 2013) After the Roman general Pompey conquered the Seleucid territories around 64 BC, the Nabatean kingdom became a client state of Rome. 170 years later, in 106 AD, the Romans fully annexed the territory into their Provincia Arabia. The specifics of how such an annexation came about is unknown, but the city continued to act as a center of trade for roughly four centuries afterwards. (Ibid)

Petra garnered even more attention after 1967. The first management plan for Petra, written in 
1968. Its title, "Master Plan for the Protection and Use of the Petra National Park," contains an interesting misnomer. There never has existed an entity known as "Petra National Park," although the idea of a "national park" for the Petra region was repeatedly suggested in successive management plans. (Akrawi, 2012) In fact, it was not until after 2006 that the exact geographic boundaries of Petra were set, despite it having been on the World Heritage List since 1985. (Comer, 2012)

Petra is a notable site in Jordan not only for its unique archaeology, geology, and history, but also for the manner in which it is managed. Unlike many other heritage sites in Jordan, Petra is managed not by the Ministry of Tourism and Antiquities alone but also by the Petra Development and Tourism Regional Authority (PDTRA). Additionally, the local population, the Department of Antiquities, and UNESCO all have some kind of say in the operation of Petra, making it a space where authority often overlaps and contradicts. In 1994, UNESCO published their "Petra National Park Management Plan." In the executive summary of the plan, the authors listed the first problem as "Management deficiency." They wrote:

Many government departments and other institutions are responsible for the site and its surrounding environment. There is no efficient mechanism to manage the PNP and coordinate inputs. Most of the underlying problems are a consequence of such a situation. (pp. 4)

While the PDTRA was formed in an effort to remedy this situation, as writes in "Forty-Four Years of Management Plans at Petra," its establishment "has only amplified unilateral decisionmaking and built a greater wedge in collaboration / coordination / communication between the PDTRA and other government stakeholders, who are impacted by PDTRA's unilateral resolve." (Akrawi, 2012)

Petra is also notable because despite its uniqueness, importance to tourism in Jordan, and worldwide profile, the site appears to have spent much of its modern existence in peril. Between 1996 and 2002, Petra was named on the World Heritage Convention's 100 Most Endangered Sites four times. (UNESCO) An archaeological park encompassing 264 dunams of land was established in either 2003 or 2007 "depending on the documents examined," (Comer, 2012, pp. 21) and the Petra Regional Authority for Development and Tourism came into being in 2009. However, according to UNESCO, a legally binding management plan for Petra has never been enacted. Since the plan proposed in 1968, four more management and master plans have followed, including one from 2011 authored by a private company. This plan strangely does not include any management issues in it at all, because "specific management issues for the [Petra Archaeological Park] were not included within the scope (ATC Consultants, 2011)

Current issues affecting the site are almost entirely linked to the overwhelming burdens placed on it by rising tourism and development. The increasing development projects around Petra have significantly augmented impermeable surface areas surrounding the site, degrading the ancient water management systems and leaving the monument prone to severely destructive flash flooding. (Comer, 2012)

\section{Methodology}

This study seeks to provide insights into how Petra has been managed since 1968 to achieve a sustainable management approach. In order to meet this main goal, interviews and a questionnaire were applied to collect the required data. Seven formal interviews were carried out with academics in the fields of tourism and archaeology, specialists of cultural resource management, tour operators, and an official at the Department of Antiquities. Every interview took place at the respective interviewee's place of work. All data in the paper was collected with the highest ethical standards possible, and with the full consent of those interviewed or surveyed. Semi-structured interviews were used for the data collection. In many cases, however, the interviewee provided information that led to new questions which were not on the sheet.

Additionally, a survey was carried out among fifty five faculty members at a Jordanian university. The survey was accompanied by a heading which stated that all results were anonymous, 
and that the data collected in the survey used in a research project. The survey consisted of five statements regarding archaeology and tourism in Jordan. Surveyed individuals were asked to rate each statement on a scale of one to ten. A rating of "one" meant the respondent "Strongly disagreed" with the statement, and a rating of "ten" meant the respondent "strongly agreed" with the statement.

Data from the questionnaire was compiled into Microsoft Excel and arranged in table 1.

Apart from interviews, traditional library research made up the bulk of the research experience to review tourism sector, and archaeology in Jordan. The secondary sources, also carries a number of primary sources related to management at Petra, including the management plan authored by UNESCO from 1994. All literary resources, both print and online, are listed in the references section at the end of the paper. Library research was conducted primarily at the American Center for Oriental Research (ACOR) library in Amman. Relevant statistics on tourism at Petra were gathered from a mixture of print and online resources, including from the Ministry of Tourism and Antiquities' website, and the Jordanian government's service.

\section{Results}

All of the interviews completed touched on one or more of three themes: local communities at Petra, the need (or lack thereof) for structural changes at the Ministry of Tourism and Antiquities, and the large number of stakeholders at Petra and the need for cooperation between them. Within the theme of local communities, interviewees expressed a common opinion that the local community at Petra needs to have a starring role in any future management plan or in any action taken there. Interviewee 1 pointed out that the local community "is involved at Petra in a way not seen at other sites, primarily because they are the original inhabitants." (Interview, 12 November 2019) Interviewee 2 expressed a similar sentiment in her interview. "The local attitude is "This place is ours," she said, "[They] can make any project fail or pass." She added, "The local people should be the priority, because they have so much power. It's hard to communicate, but they need to be the priority." (Interview, 7 November 2019) Interviewee 3, a cultural resource management expert, stated that in the field of conservation, "all issues relate to the local community. Before you make a management plan, you must include all the stakeholders. The local community is the main stakeholder." (Interview, 11 November 2019) The need for cooperation was also stressed by Interviewee 4. "There is a huge gap between professionals and academia," she said, "Academics work on studies, but professionals don't take those studies seriously. We need more cooperation between professionals and academia, and between the local community and everyone else." She went on to say that the difficulty in implementing a management plan in Petra emerged from a "lack of cooperation between the public and private sector and the local community. It isn't the Ministry of Tourism's responsibility alone [to implement a management plan.]" (Interview, 11 November 2019)

Interviewees were particularly talkative on the subject of the Ministry of Tourism and Antiquities. Opinions on the Ministry's structure and scope of authority ranged from complete opposition to enthusiastic endorsement. Among those opposed to the grouping of tourism and antiquities in the same ministry was Interviewee 6 a career archaeologist "We are part of the Ministry of Tourism, and this is wrong," she said, "We contradict each other! Tourism is about business. Archaeology is about value. [Tourism officials] look at sites as bags of money. They don't care about the value of sites. (Interview, 7 November 2019)

Interviewee 7, an archaeologist, said that "the two ministries should be separated, or the procedures should be changed, because sometimes if you want to do something archaeologically, you need permission from the Ministry of Tourism. And sometimes, the people working there don't know enough about archaeology." (Informal Interview 8, 13 November 2019)

Interviewee 2, a tourism expert, said that "there is no need for the political organization of tourism." He additionally said that the ministry should "focus on infrastructure." He believes that the role played by archaeology is greatly overstated in Jordanian tourism. "Archaeology is a minor part in the tourism phenomenon," he said. "Recent studies indicate a shift in tourist motivations, away from 
antiquities and towards adventure tourism, ecotourism, caving, safaris." When asked about the cause of such a shift, he responded: "Because tourists seek a new kind of experience, looking for something distinctive." He continued, stating that "there is a stereotype of Jordan as a cultural tourism country. (Interview, 10 November 2019)

When asked whether tourism and antiquities should be regulated under the same government ministry, Interviewee 9, a tour operator, replied, "No, I totally disagree. I think these ministries should be separated." However, he did add a caveat, remarking that one must remember "that the Department of Antiquities and the Ministry of Tourism are separate, and often contradict each other. For example, the Department of Antiquities might start excavations and the Ministry of Tourism doesn't know, because there's no communication. So, tour groups might walk in on an excavation." (Interview, 12 November 2019) another interviewee had a similar response, coming from the opposite end of the spectrum. "Tourism should be responsible for heritage and archaeology in Jordan," he said, "But, you must remember that the Department of Antiquities is separate in its budget. Sometimes this creates problems because they are essentially independent from oversight from the greater ministry." (Interview, 11 November 2019) Others' responses were more mixed, said that archaeologists "need [antiquities and tourism] to be in the same ministry. It's good because income from tourism can go towards archaeological sites." (Interview, 7 November 2019)

When asked why, in fifty-one years of management plans at Petra, no management plan had ever been implemented in full, the response was nearly unanimous from all interviewed: the many stakeholders at Petra creates too many complications for full implementation of management plans. There is the Ministry of Tourism and Archaeology, Department of Antiquities, Petra Regional Authority, and the UNESCO.

Some responses also touched on the physical aspects of the site, and the workforce there. "Petra is a big site," It needs many, many works there. The budgets might run out before the management plans are fully implemented. Sometimes strategy is flawed or not followed. This is why we get new management plans. The problem is that the plan isn't implemented." (Interview, 11 November 2019)

\subsection{Survey Responses}

Survey respondents were asked to grade five statements about tourism and archaeology on a scale of one to ten, with one meaning "strongly disagree," and ten meaning "strongly agree." The statements are numbered and identified as follows:

Table 1: Questionnaire statements

\begin{tabular}{|l|}
\hline 1) Tourism helps archaeology. \\
\hline 2) Archaeology and tourism should be regulated by the same government ministry. \\
\hline 3) Archaeology and tourism should be taught in the same school at Jordanian universities. \\
\hline 4) Archaeological/heritage tourism makes up the majority of tourism in Jordan. \\
\hline 5) Access to heritage monuments like Petra should be limited. \\
\hline
\end{tabular}

Table 2: Responses to survey

\begin{tabular}{|l|c|c|c|c|c|}
\hline Discipline: & Statement One & Two & Three & Four & Five \\
\hline CRM Averages & 8.3 & 4.8 & 7.3 & 8.8 & 6.0 \\
\hline Tourism Averages & 9.0 & 5.3 & 1.3 & 7.0 & 6.7 \\
\hline Arch Averages & 6.4 & 7.0 & 9.4 & 9.1 & 6.3 \\
\hline Overall Averages: & 7.6 & 6.0 & 7.1 & 8.6 & 6.3 \\
\hline
\end{tabular}

On average, the responses to each statement were more positive than not. The most positive average responses came from statement four ("Archaeological/heritage tourism makes up the majority of 
tourism in Jordan") at an average of 8.57 and statement one ("Tourism helps archaeology") at an average response of 7.64 . The most negative average responses came from statement two ("Archaeology and tourism should be regulated by the same government ministry") at an average response of 6 and statement five ("Access to heritage monuments like Petra should be limited") at an average of 6.28. The median averaged response was statement three ("Archaeology and tourism should be taught in the same school at Jordanian universities") at an average response of 7.07.

\section{Discussion}

With regards to the question "What do archaeologists and tourism experts think about the structure of the Ministry of Tourism and Antiquities?" it appears that attitudes encompass a full range, from hostility to indifference to endorsement. While others feel that the competing values of tourism and archaeology creates too great a gap to straddle and leads to an unfair power difference between the two disciplines, others, argue that the Department of Antiquities is separated enough from the greater Ministry. In the survey, support for the Ministry of Tourism and Antiquities was greater among the archaeologists than among the tourism experts, but their opinions also were sequestered at either ends of the spectrum, with none in the middle.

With regards to the first part, the individuals from the archaeological community surveyed and interviewed are split between those who think tourism and archaeology are destined to clash, and those who think that archaeology should adapt to the needs of tourism. Generally, interviewees agreed that there should be a balance between archaeology and sustainable tourism, it has been mentioned that tourism as a "problem" and a challenge for archaeologists today, because some thinks that tourism and archaeology have competing values. To the second part, it appears that these groups, advocates for tourism and archaeologists, are not necessarily exclusive. While some archaeologists spoke of a need to put archaeological progress over the comfort of tourists, three out of the seven archaeologists surveyed thought that "tourism helps archaeology." Furthermore, another two interviewee spoke positively about the possibility of tourism revenues going towards archaeological research, but both admitted that this was not occurring at present.

With regards to the third question, "Why has it been so difficult to implement management plans at Petra in the last fifty years?" there were a number of equally viable answers that presented themselves: the large number of stakeholders and disagreements among them, budgetary problems, the fact that some crucial stakeholders, most likely the local community, may disagree with the plan presented. The idea that management plan implementation could be scuttled by locals disagreeing with the plan is significant because it mirrors statements made by interviewees and makes sense when considering what has been written about the newly launched management plan. When examining past management plans, such as the first from 1968, it is undeniable that the local community would be loath to put forward an endorsement, as the 1968 plan.

With regards to the fourth and final question: "Which group, whether it be a ministry, a department, a regional authority, or a local community, has the most control over the physical remains of the past in Jordan?" The short answer is that it depends on the site and the kind of physical remains.

\section{Conclusion}

Petra is so integral to Jordanian national identity that, the different parties at Petra have there is no other choice but to cooperate. This year's launch of a new integrated management plan for Petra, the first "fully endorsed" one, is incredibly significant to this study. First, it shows that, while there are many stakeholders in Petra, there exists the political will for these stakeholders to unite in order to formulate a new management plan. Second, since this is apparently the first "fully endorsed" management plan ever released for the site, it perhaps shows that the relationship between the different stakeholders at Petra today resembles less of a struggle than it does a new marriage. In some 
ways, this new integrated management plan can be seen as the nuptial contract.

As Jordanian history has advanced, Petra has become more and more important. It remains in that role after decades of geopolitical strife in the region. The untold value of Petra, combined with its incredible fragility, lends an urgency to the need for collaboration among the various parties and stakeholders that exist there. Petra is unique among archaeological sites in Jordan in that its political dimensions include both national identity and inter-departmental squabbling. And it is because of the strength of its role in Jordanian identity that it was able to get its Integrated Management Plan after fifty-one years of attempts. However, only time will tell whether it the plan will be implemented in full or not.

\section{References}

Abuamoud, I., Libbin, J., Green, J. \& Al Rousan, R., 2014. Factors affecting the willingness of tourists to visit cultural heritage sites in Jordan. Journal of Heritage Tourism, 9(2), pp. 148-165.

Akrawi, A., 2012. Forty-Four Years of Management Plans at Petra. In: Tourism and Archaeological Heritage Management at Petra: Driver to Development or Destruction?. New York : Springer-Verlag, pp. 31-76.

Akrawi, A., 2012. Forty-Four Years of Management Plans in Petra. Tourism and Archaeological Heritage Management, Volume 1, pp. 31-76.

Anon., n.d. About Jordan. [Online] Available at: http://jo.one.un.org

Anon., n.d. Department of Antiquities. [Online] Available at: http://jordan.gov.jo

Arshani, S. A., 2019. Honeymooner 1 millionth visitor to Petra. [Online] Available at: stuff.co.nz

ATC Consultants, 2011. Strategic Master Plan for Petra Region, Vienna: ATC Consultants.

Barnes, J., 2011. The Sense of an Ending. New York : Alfred A. Knopf.

Bousquet, B. \& Lane, B., 1994. Jordan: Petra National Park, management plan, s.l.: UNESCO.

CBJ, 2019. The Central Bank of Jordan. [Online] Available at: http://www.cbj.gov.jo/Pages/viewpage.aspx?pageID=176 [Accessed 11 April 2020].

Comer, D. C., 2012. Petra as a Bellwether Archaeological Site on the World Heritage List . In: Tourism and Archaeological Heritage Management at Petra: Driver to Development or Destruction?. New York: SpringerVerlag, pp. 3-28.

Corbett, E., 2014. Competitive Archaeology in Jordan. Austin : University of Texas Press.

Department of Antiquities, n.d. Permits for Holding Ceremonies at Archaeological Sites. [Online] Available at: jordan.gov.jo

Dizdaroglu, S. Y., 2004. Discernment of Political Dimensions of Cultural Heritage: A Critical Evaluation of Jordan's Cultural Heritage and Tourism Politics. s.l.:(Master's Thesis - Unpublished) .

Farajat, S., 2012. The Participation of Local Communities in the Tourism Industry at Petra. In: Tourism and Archaeological Heritage Management at Petra: Driver to Development or Destruction?. New York : SpringerVerlag, pp. 145-165.

Fowler, D. D., 1987. Uses of the Past: Archaeology in the Service of the State. American Antiquity, pp. 229-248.

Jordan New Agency, 2019. Petra to record highest number of vistors in its history. [Online] Available at: www.petra.gov.jo

Jordan Times, 2019. Newly unveiled plan incorporates community integration, sustainability into Petra preservation. The Jordan Times, 26 November.

Jordan Times, 2019. Tourism revenues see 9.4\% growth - CBJ. [Online] Available at: http://jordantimes.com

Hrubcova, G., Loster, T., \& Obergruber, P. (2016). The Economic Effects of Tourism in the Group of the Least Developed Countries. Procedia Economics and Finance, 39, 476-481

Erkuş-Öztürk, H., \& Terhorst, P. (2018). Economic diversification of a single-asset tourism city: Evidence from Antalya. Current Issues in Tourism, 21(4), 422-439.

Krautkraemer, J., 1998. Nonrenewable Resource Scarcity. Journal of Economic Literature, 36(4), pp. 2065-2107.

Lightfoot, K., 1995. Culture Contact Studies: Redefining the Relationship between Prehistoric and Historical Archaeology. American Antiquity, 6o(2), pp. 199-217.

Petra Development and Tourism Regional Authority, 2015. Archaeological park. [Online] Available at: http://visitpetra.jo

Petra Development and Tourism Regional Authority, 2017. State of Conservation Report: Petra World Heritage Site, s.l.: Petra Development and Tourism Regional Authority.

Pratt, S. (2015). The economic impact of tourism in SIDS. Annals of Tourism Research, 52, 148-160. 
Roya News, 2019 . Petra expected to record highest number of visitors in its history. [Online] Available at: http://en.royanews.tv

Sevara, C., Verhoeven, G., Doneus, M. \& Draganits , E., 2017. Surfaces from the Visual Past: Recovering HighResolution Terrain Data from Historic Aerial Imagery for Multitemporal Landscape Analysis. Journal of Archaeological Method and Theory, Volume 25, p. 611-642.

Tuttle, C. A., 2013. Preserving petra sustainably (one step at a time). Journal of Eastern Mediterranean Archaeology and Heritage Studies, pp. 1-23.

UNESCO, 2019. Petra Intergrated Management Plan. [Online] Available at: en.unesco.org

UNWTO, 2017. United Nation World Tourism Organization. [Online] Available at: https://www.unwto.org/glossary-tourism-terms [Accessed 10 April 2020]. 